\title{
Comparison Learning Model Air and Tai Combined With Cognitive Conflict Strategy Againts Active Learning and Concept Understanding
}

\author{
Dodik Septian Ferdiansyah, Syaad Patmanthara, Ilham Ari Elbaith Zaeni \\ State University of Malang \\ dodikseptian1999@gmail.com
}

\begin{abstract}
There are several problems in the learning process of Basic Electricity and Electronics at SMK Negeri 8 Malang, including: (1) When learning takes place students do not pay attention and listen to the teacher when delivering material, (2) The teacher does not focus on learning activities to students, (3) Students are less active in asking and expressing his opinion about the material that has been taught. This study uses a variety of learning models and methods that can improve students' learning activeness and conceptual understanding, namely the Auditory, Intellectual, Repetition (AIR) learning model and the Team Assisted Individualization (TAI) learning model, each of which is combined with cognitive conflict strategies. The research design used a quasi experimental design with a non-equivalent control group design type. The data analysis technique consisted of normality test, homogeneity test, two mean similarity test, and hypothesis testing. The conclusion of this study is that the AIR learning model combined with cognitive conflict strategies is superior to the TAI learning model combined with cognitive conflict strategies.
\end{abstract}

Keywords: Learning model, cognitive conflict strategy, concept understanding, AIR learning model, TAI learning model, active learning

Based on the 2013 curriculum, Basic Electricity and Electronics is one of the subjects included in the basic category of expertise programs taught to class $\mathrm{X}$ students of the Mechatronics expertise program with a total of 180 lesson hours for two semesters. There are two classes in class $\mathrm{X}$ of the Mechatronics expertise program with details, class X Mechatronics A with a total of 32 students and class X Mechatronics B with a total of 35 students.

Based on direct observations in class $\mathrm{X}$ Mechatronics A and B at SMK Negeri 8 Malang, it is found that teachers of Basic Electricity and Electronics subjects have applied the Discovery Learning learning model in the learning process in the classroom. However, students have not been able to understand the material being taught and do not play an active role when learning activities take place. This is because students only listen and listen to the information conveyed by the teacher. Students lack initiative and tend to be silent when the teacher instructs them to ask questions related to material that has not been understood. If this is allowed, students will become passive individuals and can interfere with learning activities.
In addition to the problem of student activeness and activity when learning, the average value obtained by class X Mechatronics A in the Basic Electricity and Electronics subject is 80 . Meanwhile, class X Mechatronics B students also get an average value of 78 . The average value of Both classes have achieved the KKM score of 76, but as interviews were conducted directly with the teacher and some students, it was found that most students still had difficulty learning concepts and processing new concepts related to the material that had been received.

When the teacher instructs students to rewrite and present the material that has been delivered, students tend to repeat and present the concept from the teacher. Meanwhile, the teacher has instructed the students to process existing concepts into new concepts, so that it will be easier for the students to understand. Increasing the ability to understand concepts in Basic Electrical subjects for students, it is necessary to provide variations in learning models and methods that can stimulate students' ability to accept concepts and process new concepts. 
Based on the facts obtained from interviews with teachers and observations in class $\mathrm{X}$ Mechatronics $\mathrm{A}$ and $\mathrm{B}$, it can be concluded that the cause of the problem arises, namely that the teacher has not applied variations in learning models and methods that can stimulate student activeness and activity in the learning process. This study takes the initiative to use a variety of learning models and methods that can increase learning activeness so that it can support a stronger understanding of concepts related to Basic Electrical and Electronics subjects, namely the Auditory Intellectually Repetition (AIR) model combined with cognitive conflict strategy methods and the Team Assisted Individualization model (TAI) combined cognitive conflict strategy methods.

Cognitive conflict strategy is a conceptual change strategy that allows students to make students aware of the misconceptions that have been built. Each student will be able to develop and combine the initial concepts that have been built with the new concepts that have been received. So that with the use of this method, each of which will be combined with the Auditory Intellectually Repetition (AIR) model and the Team Assisted Individualization (TAI) model can increase student learning activeness and the ability to understand students' concepts related to Basic Electrical and Electronics subjects.

The Auditory Intellectually Repetition (AIR) learning model combined with cognitive conflict strategies will be applied to experimental class A, namely class X Mechatronics A, totaling 32 students. The choice of this learning model is because based on Mustaqimah's research results it shows that the Auditory, Intellectually, Repetition (AIR) model with the cooperative method setting is more effective in increasing students' conceptual understanding compared to the teacher center learning model.

The Team Assisted Individualization (TAI) learning model combined with cognitive conflict strategies will be applied to experimental class B, namely class X Mechatronics B, which consists of 35 students. The choice of this learning model is because based on the results of Alimuddin, H's research, the Team Assisted Individualization (TAI) model is a learning model that can improve learning outcomes and make students more active in learning activities.
Based on the background description above, to reveal the combination of effective learning models and methods, it is necessary to compare the application of learning models and methods. So a research was carried out with the title, "Comparison Learning Model AIR And TAI Combined With Cognitive Conflict Strategy Againts Active Learning And Concept Understanding".

\section{METHOD}

This research uses experimental research methods. The research design used by the researcher is a quasi experimental design (quasiexperimental design), with a non-equivalent control group design design which is almost the same as the pretest-posttest control group design. An overview of the research design can be seen in Figure 1.

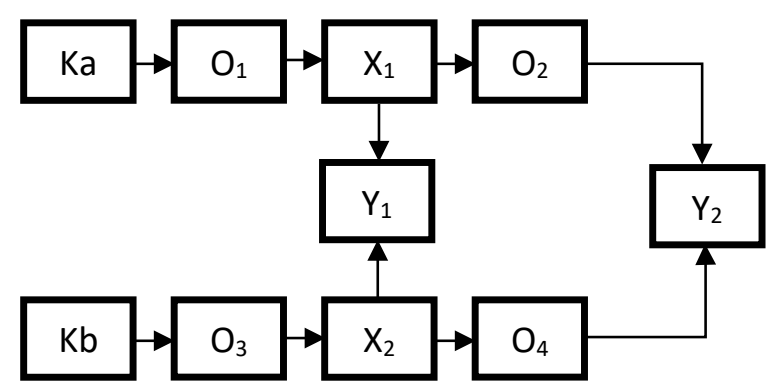

Figure 1. Research Design

Information:

Ka : Experiment class A.

$\mathrm{Kb} \quad$ : Experiment class B

$\mathrm{O}_{1}, \mathrm{O}_{3}$ : Giving pre-test questions

$\mathrm{X}_{1} \quad$ : Integrated AIR learning model

cognitive conflict strategy methods

$\mathrm{X}_{2} \quad$ : Integrated TAI learning model

cognitive conflict strategy methods

$\mathrm{O}_{2}, \mathrm{O}_{4}$ : Giving post-test questions

$\mathrm{Y}_{1} \quad$ : Active learning

$\mathrm{Y}_{2} \quad$ : Understanding the concept

The subjects of this study were students of class X Mechatronics at SMK Negeri 8 Malang in the 2019/2020 academic year which consisted of 2 classes, namely class X Mechatronics A with a total of 32 students who would be given the Auditory, Intellectual, Repetition (AIR) learning 
model combined with strategic methods. Cognitive conflict and class X Mechatronics B with a total of 35 students who will be given the Team Assisted Individualization (TAI) learning model treatment combined with cognitive conflict strategy methods.

The treatment instruments used were (1) syllabus, (2) lesson plan (RPP), and (3) teaching materials. The measurement instruments used were in the form of objective test questions and activity observation sheets. There are several stages in analyzing research data, namely, (1) descriptive analysis, (2) prerequisite analysis, and (3) research hypothesis testing.

In the descriptive analysis stage, students 'initial ability data were processed, learning activity data, concept understanding data, and students' final ability data as descriptions. In describing the result data, data are grouped into several categories based on Sudijono's formula. The range of values obtained are as follows: (a) Very low category with a range of values (15-35), (b) Low category with a range of values (36-49), (c) Medium category with a range of values (5064) , (d) High category with a range of values (6579 ) and (e) Very high category with a range of values (80-100).

In the prerequisite analysis stage, the data on the students 'initial abilities, data on learning activeness, and data on the students' final ability to understand concepts were processed. The data were processed using the normality test, homogeneity test, and similarity test for the two initial averages. Normality test uses the ShapiroWilk method with the help of IBM SPSS Statistics 23 software. Based on Uyanto's formula, the guideline for decision making is, if the significance value is $>0.05$ then the data is normally distributed, whereas if the significance value is $<0.05$ then the data is not normally distributed.

The homogeneity test uses the Levene's method with the help of IBM SPSS Statistics 23 software. Guidelines for decision making are as follows, if the significance value is $>0.05$, the data is said to be homogeneous or has the same variant, if the significance value is $<0.05$ then the data is said to be not homogeneous or its variants not the same. The similarity test for the two initial students' initial averages uses the Independent Sample t Test with the help of IBM SPSS Statistics
23 software. Guidelines for decision making are if the Sig (2-tailed) value is $>0.05$ then, $\mathrm{H}_{0}$ is accepted, but if the $\mathrm{Sig}\left(2\right.$ - tailed) $<0.05$ then $\mathrm{H}_{0}$ is rejected.

At the research hypothesis testing stage, it was used to determine the significance of differences in student learning activeness and conceptual understanding due to the influence of the AIR learning model compared to applying the TAI learning model combined with cognitive conflict strategy methods. Hypothesis testing for the significance of differences in learning activeness $\left(\mathrm{Ha}_{1}\right)$ using the $\mathrm{t}$ test (Independent Sample t-Test) with the help of IBM SPSS Statistics 23 software. Hypothesis testing for the significance of differences in understanding concepts $\left(\mathrm{Ha}_{2}\right)$ uses the $t$ test (Independent Sample $\mathrm{t}$-Test). The decision-making criteria, namely if the significance value $(\mathrm{p})>0.05$, then $\mathrm{Ha}_{1}$ and $\mathrm{Ha}_{2}$ are rejected, meaning that there is no significant difference in $\mathrm{Ha}_{1}$ or $\mathrm{Ha}_{2}$ in experimental class $\mathrm{A}$ and experimental class $\mathrm{B}$. If the significance value (p) $<0$, 05, then $\mathrm{Ha} 1$ and $\mathrm{Ha} 2$ are accepted, meaning that there is a significant difference in $\mathrm{Ha}_{1}$ and $\mathrm{Ha}_{2}$ in experimental class $\mathrm{A}$ and experimental class B.

\section{RESULTS AND DISCUSSION}

\section{Results}

\section{Student Initial Ability Data}

Data on students' initial ability were obtained from giving pretest questions to experimental class $\mathrm{A}$ and $\mathrm{B}$ in this case class $\mathrm{X}$ Mechatronics A and B at SMK Negeri 8 Malang. The pretest questions were given before receiving the Auditory, Intellectual, Repetition (AIR) model treatment combined with the cognitive conflict strategy method in experimental class A and the Team Assisted Individualization (TAI) model combined with the cognitive conflict strategy method in the experimental class B. seen in Figure 2. 


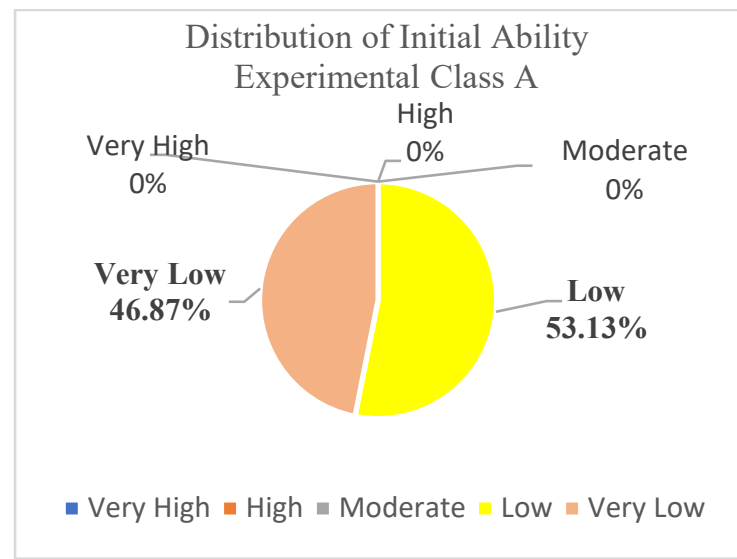

Figure 2. Initial Ability Experiment Class A

The data description of the initial ability of experimental class B can be seen in Figure 3.

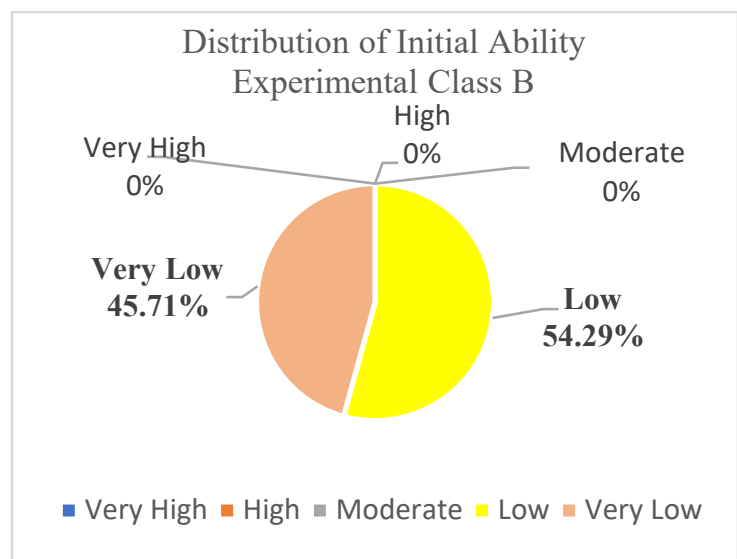

Figure 3. Initial Ability Experiment Class B

Student Learning Activity Data

Data on student learning activeness were obtained from observation sheets. The observation sheets used to measure student learning activeness were given the Auditory, Intellectual, Repetition (AIR) combined with cognitive conflict strategy methods in experimental class A and the Team Assisted Individualization (TAI) combined with cognitive conflict strategy methods in experimental class B. The data description of learning activeness in experimental class A can be seen in Figure 4.

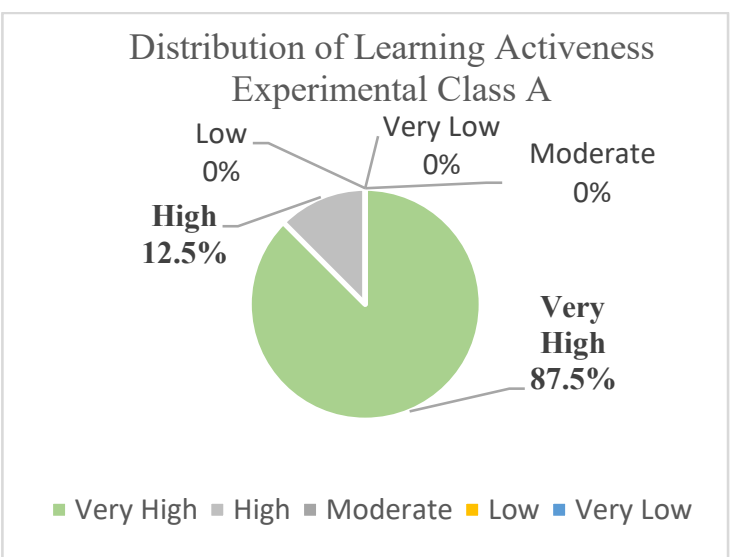

Figure 4. Learning Activity Experiment Class A

The description of the learning activity data for experimental class B can be seen in Figure 5.

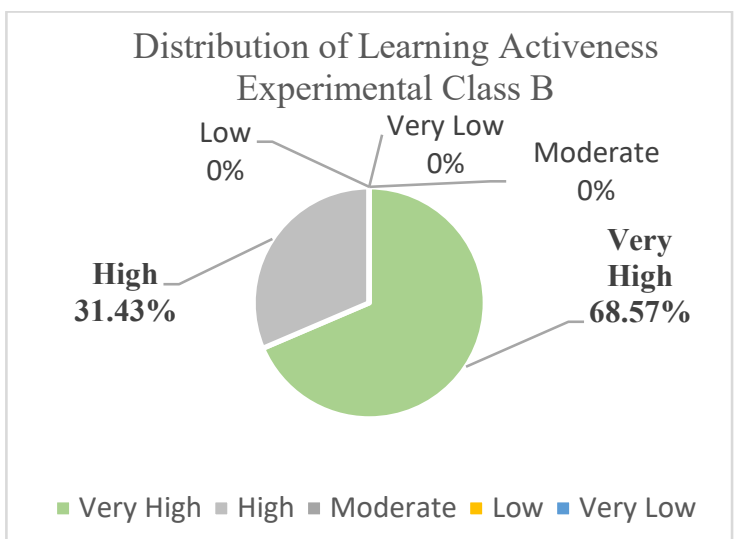

Figure 5. Learning Activity Experiment Class B

\section{Student Concept Understanding Data}

Students' conceptual understanding data were obtained from the percentage level of understanding at the time of giving the posttest questions. The posttest questions were given after receiving treatment in experimental class A and B. Description of the conceptual understanding of experimental class A data seen in Figure 6. 
Distribution of Understanding the

Concept Experimental Class A

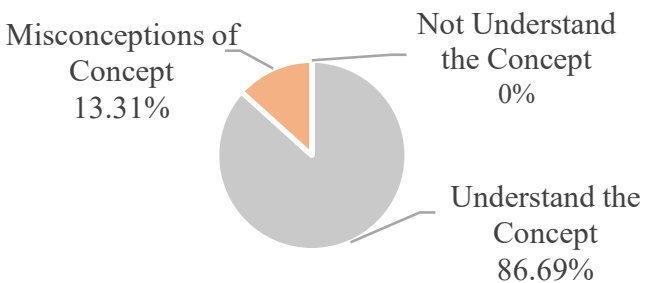

- Understand the Concept $\quad$ Misconceptions of Concept

Not Understand the Concept

\section{Figure 6. Understanding the Concept of Experiment Class A}

The data description for understanding the concept of experimental class B can be seen in Figure 7.

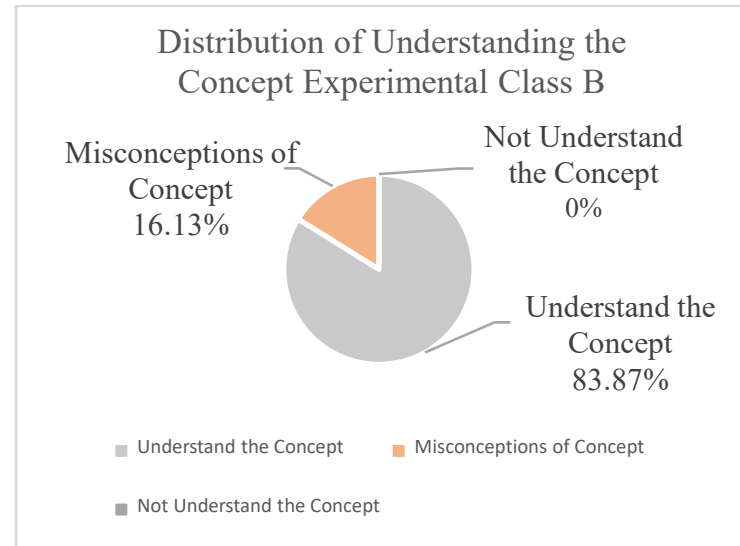

\section{Figure 7. Understanding the Concept of Experiment Class B}

\section{Student Cognitive Data}

Student cognitive data were obtained from giving posttest questions to experimental classes A and B. Description of cognitive data for experimental class A can be seen in Figure 8.

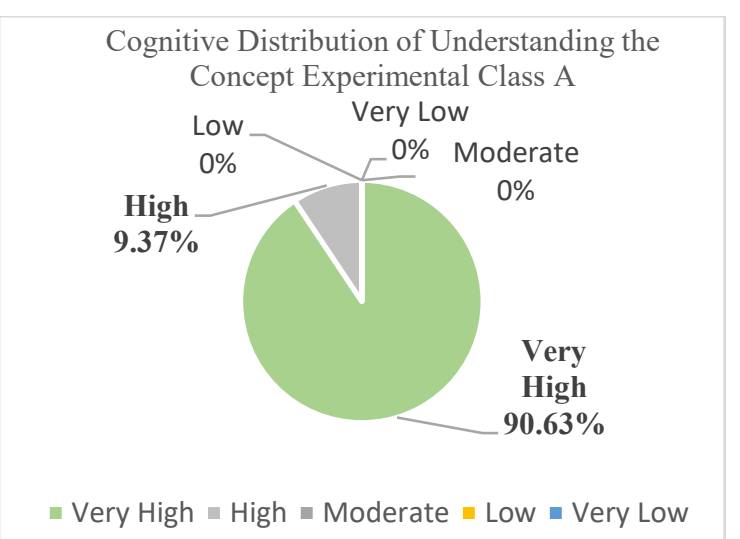

Figure 8. Cognitive Data Experiment Class A

The description of the cognitive data for experimental class B can be seen in Figure 9.

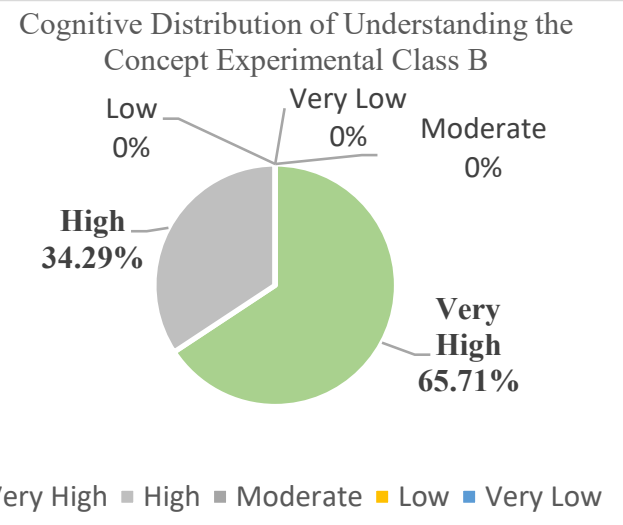

Figure 9. Cognitive Data Experiment Class B

\section{Normality Test of Student Learning \\ Activeness}

The results of the normality test of student learning activeness in experimental class $\mathrm{A}$ and experimental class B used the Shapiro-Wilk method which can be seen in Table 1 .

Table 1. Normality Test of Student Learning Activeness

\begin{tabular}{llll}
\hline \multirow{2}{*}{ Class } & \multicolumn{2}{l}{ Shapiro-Wilk } & \\
\cline { 2 - 4 } & Statistics & Df & Sig. \\
\hline $\begin{array}{l}\text { Experiment } \\
\text { A }\end{array}$ &, 950 & 32 &, 144 \\
$\begin{array}{l}\text { Experiment } \\
\text { B }\end{array}$ &, 945 & 35 & 080 \\
\cline { 2 - 4 } & & & \\
\hline
\end{tabular}

\section{Normality Test of Students' Concept Understanding}

The results of the normality test for understanding the concept of students in experimental class A and experimental class B used the Shapiro-Wilk method which can be seen in Table 2.

Table 2. Normality Test of Students' Concept Understanding

\begin{tabular}{cccc}
\hline \multirow{2}{*}{ Class } & \multicolumn{3}{c}{ Shapiro-Wilk } \\
\cline { 2 - 4 } & Statistics & Df & Sig. \\
\hline Experiment A &, 947 & 32 &, 120 \\
\cline { 2 - 4 } Experiment B &, 950 & 35 &, 110 \\
\hline
\end{tabular}

Homogeneity Test of Student Learning Activeness The results of the homogeneity test of student learning activeness in experimental class A and experimental class B using Levene's method which can be seen in Table 3. 
Table 3. Homogeneity Test of Student Learning Activeness

\begin{tabular}{lll}
\hline Class & Sig. & Information \\
\hline Experiment A &, 275 & Homogeneous \\
Experiment B & & \\
\hline
\end{tabular}

Homogeneity Test of Students' Concept Understanding

The results of the homogeneity test of students' concept understanding in experimental class A and experimental class B used Levene's method which can be seen in Table 4.

Table 4. Homogeneity Test of Students' Concept Understanding

\begin{tabular}{lll}
\hline Class & Sig. & Information \\
\hline Experiment A &, 852 & Homogeneous \\
Experiment B & & \\
\end{tabular}

Similarity Test of Two Initial Average Abilities The results of the two similarities test mean that the students' initial ability of experimental class A and experimental class B used the Independent Sample t Test which can be seen in Table 5 .

Table 5. Similarity Test of Two Initial Average Abilities

\begin{tabular}{llll}
\hline & \multicolumn{3}{l}{$\begin{array}{l}\text { T-Test For Equality Of } \\
\text { Means }\end{array}$} \\
\cline { 2 - 4 } & T & Df & $\begin{array}{l}\text { Sig. } \\
(2- \\
\text { Tailed })\end{array}$ \\
\hline Equal variance assumed & $\begin{array}{l}-, \\
577\end{array}$ & 65 &, 566 \\
$\begin{array}{l}\text { Equal variance not } \\
\text { assumed }\end{array}$ & $\begin{array}{l}-, \\
578\end{array}$ & 64,809 &, 565 \\
\hline
\end{tabular}

Hypothesis Test of Student Learning Activeness Hypothesis testing of learning activeness in both classes uses the t-test which can be seen in Table 6 .

Table 6. Hypothesis Test of Student Learning Activeness

\begin{tabular}{llll}
\hline & \multicolumn{2}{l}{$\begin{array}{l}\text { T-Test For Equality Of } \\
\text { Means }\end{array}$} \\
\cline { 2 - 4 } & T & Df & $\begin{array}{l}\text { Sig. } \\
(2- \\
\text { Tailed })\end{array}$ \\
\hline $\begin{array}{l}\text { Equal variance } \\
\text { assumed }\end{array}$ & 2,265 & 65 &, 027 \\
$\begin{array}{l}\text { Equal variance not } \\
\text { assumed }\end{array}$ & 2,282 & 64,618 &, 026 \\
\hline
\end{tabular}

Hypothesis Test of Students' Concept Understanding
Hypothesis testing on conceptual understanding in both classes uses the t-test which can be seen in Table 7.

Table 7. Hypothesis Test of Students' Concept Understanding

\begin{tabular}{llll}
\hline & \multicolumn{2}{l}{$\begin{array}{l}\text { T-Test For Equality Of } \\
\text { Means }\end{array}$} \\
\cline { 2 - 4 } & T & Df & $\begin{array}{l}\text { Sig. } \\
(2- \\
\text { Tailed })\end{array}$ \\
\hline $\begin{array}{l}\text { Equal variance } \\
\text { assumed }\end{array}$ & 2,886 & 65 &, 005 \\
$\begin{array}{l}\text { Equal variance not } \\
\text { assumed }\end{array}$ & 2,890 & 64,764 &, 005 \\
\hline
\end{tabular}

\section{DISCUSSION}

Description of Students' Concept Understanding Ability with Auditory, Intellectually, Repetition (AIR) Learning Model Combined with Cognitive Conflict Strategy Methods

This research was conducted in class $\mathrm{X}$ Mechatronics A as experimental class A with KD material. 3.18, namely analyzing the work of basic digital electronics circuits on basic electricity and electronics subjects by applying the Auditory, Intellectually, Repetition (AIR) learning model combined with the cognitive conflict strategy method.

The data on the results of students' conceptual understanding in experimental class A obtained the highest score of 96 and the lowest score of 68 with an average value obtained of 85.75. With the acquisition of an average value of 85.75 , it can be concluded that students' conceptual understanding by applying the Auditory, Intellectually, Repetition (AIR) learning model combined with the cognitive conflict strategy method has very high criteria. The acquisition of this value has increased compared to the initial ability before being given the learning model treatment, namely the initial ability average value of 34.5 increased to 85.75 .

The data on the results of student conceptual understanding that have been obtained are in line with research conducted by Mustaqimah (2012) which states that the Auditory, Intellectually, Repetition (AIR) learning model with the cooperative learning method setting is more effective in increasing students' 
conceptual understanding compared to the use of a teacher center learning model.

Based on the students 'conceptual understanding data obtained, it can be concluded that the application of the Auditory, Intellectually, Repetition (AIR) learning model combined with the cognitive conflict strategy method can improve students' conceptual understanding in the cognitive domain. The increase occurred because at each stage of the learning process students held discussions between groups and held debates and rebuttals during group presentations in front of the class. This encourages all students in the class to be actively involved in learning and the teacher provides repetition of the material at the end of the lesson so that students can remember and reinforce the material that has been learned.

Description of Student Learning Activeness with Auditory, Intellectually, Repetition (AIR) Learning Model Combined with Cognitive Conflict Strategy Methods

This research was conducted in class $\mathrm{X}$ Mechatronics A as experimental class A with KD material. 3.18, namely analyzing the work of basic digital electronics circuits on basic electricity and electronics subjects by applying the Auditory, Intellectually, Repetition (AIR) learning model combined with the cognitive conflict strategy method.

The data on the results of student learning activeness in the experimental class A obtained the highest activity value of 100 and the lowest activity value of 78.6 with the resulting average value of 88.13. With the acquisition of an average value of 88.13 , it can be concluded that student learning activeness by applying the Auditory, Intellectually, Repetition (AIR) learning model combined with the cognitive conflict strategy method has very high criteria. The data on student learning activeness that has been obtained is in line with research conducted by Mita S, et al. (2014) which states that the Auditory, Intellectually, Repetition (AIR) learning model can improve student learning outcomes in the cognitive and affective domains.

On the observation sheet, there are assessment criteria for each indicator of each student's learning activeness obtained from expert Sardiman (2009: 100-101). The indicators of student learning activity include, (a) Visual activities, (b) Oral activities, (c) Listening activities, (d) Writing activities, (e) Motor Activities, (f) Drawing activities, (g) Mental activities, (h) Emotional activities.

The scores for each indicator of student learning activeness include, (a) Visual activities with a total score of 116, (b) Oral activities with a total score of 115.5 , (c) Listening activities with a total score of 111, (d) Writing activities with a total score of 112, (e) Drawing activities with a total score of 110.5, (f) Mental activities with a total score of 113, (g) Emotional activities with a total score of 115.5.

Based on the data on the results of learning activeness obtained, it can be concluded that the application of the Auditory, Intellectually, Repetition (AIR) learning model combined with the cognitive conflict strategy method can increase student learning activeness in the affective domain. The increase occurred because at each stage of the learning process students held discussions between groups and held debates and rebuttals during group presentations in front of the class. This statement is in line with the research conducted by Nirawati (2009) which states that the Auditory, Intellectually, Repetition (AIR) learning model gets a positive response because students think the learning process is very enjoyable and makes students more active in learning activities.

Description of Students' Concept Understanding Ability with Team Assisted Individualization (TAI) Learning Model Combined with Cognitive Conflict Strategy Methods

This research was conducted in class $\mathrm{X}$ Mechatronics B as experimental class B with $\mathrm{KD}$ material. 3.18, namely analyzing the work of the basic digital electronics circuit in basic electricity and electronics subjects by applying the Team Assisted Individualization (TAI) learning model combined with the cognitive conflict strategy method.

The data from the students' conceptual understanding in the experimental class B obtained the highest score of 92 and the lowest score of 68 with an average value obtained of 81.1. With the acquisition of an average value of 81.1, it can be concluded that students' understanding of the concept by applying the Team Assisted 
Individualization (TAI) learning model combined with the cognitive conflict strategy method has very high criteria. The acquisition of this value has increased compared to the initial ability before being given the learning model treatment, namely the initial ability average value of 35.3 increases to 81.1 .

Based on the data obtained from the students 'conceptual understanding, it can be concluded that the application of the Team Assisted Individualization (TAI) learning model combined with the cognitive conflict strategy method can improve students' understanding of concepts in the cognitive realm. The increase occurred because the Team Assisted Individualization (TAI) learning model applied a combination of two learning methods, namely learning individually and learning in groups. Students are required to be responsible for the learning material studied individually, then students must discuss in groups to solve problems that have been given by the teacher. This statement is in line with research conducted by Alimuddin, $\mathrm{H}$ (2017) which states that the Team Assisted Individualization (TAI) learning model is a learning model that can improve learning outcomes and make students more active in learning activities.

Description of Student Learning Activities with Team Assisted Individualization (TAI) Learning Models Combined Cognitive Conflict Strategy Methods

The application of the Team Assisted Individualization (TAI) learning model combined with the cognitive conflict strategy method during the learning process in the classroom is more emphasized on giving assignments that contain cognitive problems which are done in groups. This research was conducted in class X Mechatronics B as an experimental class B with KD material. 3.18, namely analyzing the work of the basic series of digital electronics in the basic subjects of electricity and electronics with the application of the Team Assisted Individualization (TAI) learning model combined with the cognitive conflict strategy method. This study measures and assesses student learning activities.

Data on the results of student learning activeness in experimental class B obtained the highest activity value of 100 and the lowest activity value of 75 with an average value of
84.67. With the acquisition of an average value of 84.67 , it can be concluded that students' learning activeness by applying the Team Assisted Individualization (TAI) learning model combined with the cognitive conflict strategy method has very high criteria. Data on the results of student learning activeness that has been obtained in line with research conducted by Alimuddin, H (2017) states that the learning model of Team Assisted Individualization (TAI) can improve student learning activeness with an average range of values of 75.26 .

Data on the results of students' learning activeness was obtained from an observation sheet that was filled out by the observer when the learning activities took place. On the observation sheet there are assessment criteria on each indicator of learning activeness of each student obtained from expert Sardiman (2009: 100-101). The indicators of student learning activeness include, (a) Visual activities, (b) Oral activities, (c) Listening activities, (d) Writing activities, (e) Motor Activities, (f) Drawing activities, (g) Mental activities, (h) Emotional activities.

Obtaining a score on each indicator of student learning activeness, among others, (a) Visual activities with a total score of 118.5 , (b) Oral activities with a total score of 117 , (c) Listening activities with a total score of 117.5, (d) Writing activities with a total score of 119.5 , (e) Drawing activities with a total score of 116.5, (f) Mental activities with a total score of 116.5 , (g) Emotional activities with a total score of 123 .

Based on the data of learning activeness results obtained, it can be concluded that the application of the Team Assisted Individualization (TAI) learning model combined with cognitive conflict strategy methods can increase student learning activeness. Improvement occurs because students are required to be responsible for learning material that is studied individually, then students must discuss in groups to solve problems that have been given by the teacher. So students feel happy and challenged to solve problems together and can also help each other between groups.

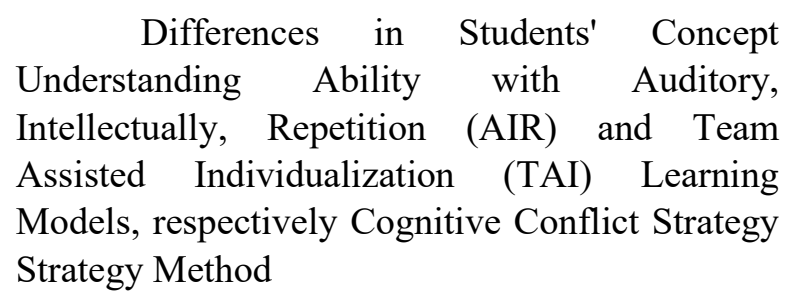

Differences in Students' Concept Understanding Ability with Auditory, Intellectually, Repetition (AIR) and Team Assisted Individualization (TAI) Learning Models, respectively Cognitive Conflict Strategy Strategy Method 
The average initial ability value of the experimental class A was 34.5 which had very low criteria, while the experimental class B was 35.3 which had very low criteria. The average value of the final ability of experimental class A is 85.75 which has very high criteria, while experimental class $\mathrm{B}$ is 81.1 which has very high criteria. The acquisition of the average value of the final ability of the two classes has increased compared to the average value of the initial ability of the two classes, so it can be concluded that the Auditory, Intelectually, Repetition (AIR) learning model and the Team Assisted Individualization (TAI) learning model respectively - combined cognitive conflict strategy methods can improve students' understanding of concepts in the cognitive domain.

In the experimental class A shows the concept understanding data at the conceptual understanding level obtained a percentage of $86.69 \%$. The concept of misconception concept obtained a percentage of $13.31 \%$. The level of not understanding the concept gets a percentage of $0 \%$. Whereas the experimental class B showed that the concept understanding data at the conceptual understanding level obtained a percentage of $83.87 \%$. The concept misconception level obtained a percentage of $16.13 \%$. The level of not understanding the concept gets a percentage of $0 \%$.

Based on the data understanding of the concepts of the two experimental classes, it can be concluded that the experimental class $\mathrm{A}$ has a value of $6 \%$ higher than the experimental class $B$. So it can be concluded that the application of the Auditory learning model, Intelectually, Repetition (AIR) combined with cognitive conflict strategy methods is superior in improving students' understanding of concepts compared to the application of the Team Assisted Individualization (TAI) learning model combined with cognitive conflict strategy methods.

Differences in Student Learning Activities with Auditory, Intellectually, Repetition (AIR) and Team Assisted Individualization (TAI) Learning Models, respectively Cognitive Conflict Strategy Strategy Method

Student learning activeness data obtained from the observation sheet during learning in experimental class A and experimental class B in this case class $\mathrm{X}$ Mechatronics A and B in SMK Negeri 8 Malang. Observation sheets are used to measure student learning activeness by treating the Auditory, Intellectual, Repetition (AIR) and Team Assisted Individualization (TAI) models, each of which is combined with cognitive conflict strategy methods. The average value of learning activeness of experimental class A is 88.13 which has very high criteria, while the average value of learning activeness of experimental class B is 84.67 which has very high criteria.

Based on the data of learning activeness results from the two experimental classes, it can be concluded that the experimental class $\mathrm{A}$ has a value of $4 \%$ higher than the experimental class $B$. So it can be concluded that the application of the Auditory, Intellectual, Repetition (AIR) learning model combined with cognitive conflict strategy methods is superior in increasing student learning activeness compared to the application of the Team Assisted Individualization (TAI) learning model combined with cognitive conflict strategy methods.

\section{CONCLUSION}

Students' conceptual understanding ability has increased after being given treatment using Auditory, Intellectually, Repetition (AIR) learning models combined with cognitive conflict strategies. With the acquisition of an initial average value of 34.5 , it increases to 85.75 , so it can be concluded that the ability to understand the concept has very high criteria. Student learning activeness has increased with the highest score of 100 and the lowest score of 78.6 with an average value of 88.13 , it can be concluded that learning activeness has very high criteria.

Students' conceptual understanding ability has increased after being given treatment using the Team Assisted Individualization (TAI) learning model combined with cognitive conflict strategies. With the acquisition of an initial average value of 35.3 , it increases to 81.1 , so it can be concluded that the ability to understand the concept has very high criteria. Student learning activeness has increased with the highest score of 100 and the lowest score of 75 with an average value of 84.67 , it can be concluded that learning activeness has very high criteria. 


\section{REFERENCES}

Afrilianto, M. 2012. Peningkatan pemahaman konsep dan kompetensi strategis matematis siswa smp dengan pendekatan metaphorical thinking. Infinity Journal, 1(2), 192-202.

Alimuddin, H. 2017. Pengaruh Keaktifan Belajar Siswa Melalui Penerapan Model Pembelajaran Kooperatif Tipe Team Assisted Individualization (TAI) Terhadap Hasil Belajar Matematika Siswa Kelas Vii Smp Negeri 4 Satap Bungoro. Jurnal Histogram Vol. 1 No. 1. Prodi Pendidikan Matematika: STKIP Andi Matappa Pangkep.

Fauzi, A., \& Winarti, A. 2015. Meningkatkan Keterampilan Berpikir Kritis dan Hasil Belajar Siswa melalui Model Pembelajaran Auditory, Intellectually, Repetition (AIR) Materi Hidrolisis Garam Kelas XI IPA SMA PGRI 6 Banjarmasin. Jurnal Inovasi Pendidikan Sains, 1-10.

Marheni, N. L. G., Sujana, I. W., \& Putra, D. K. N. S. 2013. Penerapan Model Pembelajaran Kooperatif Tipe STAD Untuk Meningkatkan Keaktifan Dan Hasil Belajar Ips Kelas V Sd No. 8 Padangsambian Denpasar. MIMBAR PGSD Undiksha, 1(1).

Syahliani, M., Jamal, M. A., \& An'nur, S. (2014). Penerapan Model Pembelajaran Auditory Intelectually Repetition (AIR) Untuk Meningkatkan Hasil Belajar Siswa. Jurnal Ilmiah Pendidikan Fisika Vol. 2 No. 3. Prodi Pendidikan Fisika FKIP: UNLAM Banjarmasin.

Mufarridah, M., Supardi, Z. I., \& Prastowo, T. (2017). Upaya Mereduksi Miskonsepsi Siswa Pada Materi Bahasan Rangkaian Listrik Sederhana Melalui Model Pembelajaran Kooperatif Dengan Strategi Konflik Kognitif. Jurnal Penelitian Pendidikan Sains Vol. 3 No. 1. Universitas Negeri Surabaya: Pasca Sarjana Pendidikan Sains.

Mustaqimah. 2012. Efektivitas Model Pembelajaran AIR (Auditory, Intellectually, Repetition) Dengan Setting Model Pembelajaran Kooperatif Tipe TGT (Teams GamesTournament)TerhadapPemahaman Konsep dan Motivasi Belajar Matematika Siswa Kelas VIII SMP Negeri 15 Yogyakarta. UIN Sunan Kalijaga Yogyakarta: Jurnal diterbitkan.

Nirawati, N. 2009. Pengaruh Model AIR (Auditory Intellectually Repetition) dalam Pembelajaran Matematika Terhadap Kompetensi Strategi (Strategic Competence) Siswa SMP. Bandung: FMIPA UPI.
Ratnawati, A. 2014. Pengaruh Kesiapan Belajar, Minat Belajar, Motivasi Belajar, dan Sikap Siswa Terhadap Keaktifan Belajar Siswa Jurusan Administrasi Perkantoran Pada Mata Diklat Produktif Ap Di Smk Negeri 2 Semarang. Economic Education Analysis Journal, 3(1).

Ridia, N. S., \& Afriansyah, E. A. 2019. Perbandingan Kemampuan Pemahaman Matematis Siswa melalui Auditory Intellectualy Repetition dan Student Teams Achievement Division. Mosharafa: Jurnal Pendidikan Matematika, 8(3), 515-526.

Ririn. 2015. Penerapan Model Pembelajaran Kooperatif Tipe TAI (Team Assisted Individualization) Dalam Meningkatkan Keaktifan Belajar dan Pemahaman Konsep Pada Pelajaran Matematika Siswa Kelas XI Di SMK Negeri 1 Jayapura. Jurnal Ilmu Pendidikan Indonesia Vol. 3 No. 3. Universitas Cenderawasih.

Sangadji, Etta \& Sopiah. 2010. Metodologi PenelitianPendekatan Praktis dalam Penelitian. Yogyakarta: ANDI.

Sardiman, A M. 2009. Interaksi dan Motivasi Belajar Mengajar. Jakarta: PT. Rajawali Pers.

Sudijono, A. 2011. Pengantar Evaluasi Pendidikan. Jakarta: Rajawali Pers.

Sugiyono. 2013. Metodelogi Penelitian Kuantitatif, Kualitatif dan R\&D. Bandung: Alfabeta.

Sugiyono. 2011. Metode Penelitian Kuantitatif, Kualitatif dan R\&D. Bandung: Alfabeta.

Tinungki, G. M. 2015. The Role of Cooperative Learning Type Team Assisted Individualization to Improve the Students' Mathematics Communication Ability in the Subject of Probability Theory. Journal of Education and Practice, 6(32), 27-31.

Trianto. 2010. Model Pembelajaran Terpadu. Jakarta: Bumi Aksara.

Uyanto, Stanislaus S. 2009. Pedoman Analisis Data dengan SPSS. Yogyakarta: Graha Ilmu.

Verawati, N. N. S. P., Kosim, K., Gunawan, G., \& Arizona, K. (2017). Pengembangan Bahan Ajar Fisika Berbasis Lkm Ceria Untuk Meningkatkan Keterampilan Berpikir Kritis Dan Kreatif Mahasiswa Calon Guru Fisika. Jurnal Ilmiah Pendidikan Fisika "Lensa” Vol. 5 No.1, ISSN 2338-4417. IKIP Mataram 